regional pedology and meteorology, organic manuring, mechanization, forestry, selective weed-killers, and economic and agricultural botany. The publication is designed mainly for circulation to scientific institutions; its subject-matter and format are of a high standard, and most papers have reasonably good summaries in French and English, but many of them lack bibliographical references. To cater for growers, "Agronomia Angolana" has established an extension service which will produce bulletins and leaflets for distribution to growers, incorporating the relevant information in a more popular form.

\section{Collection of Bygone Agricultural Implements}

THE collecting of early agricultural implements is an imperative necessity at the present time if any of the fast-disappearing types are to be preserved for posterity. Many museums are engaged in this important task, and the Gloucester Folk Museum, housed in Bishop Hooper's Lodging, in addition to collecting and displaying such material, has issued a handy and authoritative guide to its agricultural collections, entitled "Guide to the Collection of Bygone Agricultural Implements" (pp. 20+4 plates; Gloucester : Folk Museum, 1950; 9d.). The material is appropriately grouped under the operations of ploughing, sowing and cultivation, haymaking and harvesting, ricking, thatching and threshing, with an added section for certain miscellaneous farm imple. ments. Each section is prefaced by some useful general remarks on the subject, written by $J$. N. Taylor, the curator.

\section{Archives of Biochemistry and Biophysics}

Beginning with Vol. 31, No. 1 (March 1951), the title of Archives of Biochemistry has been altered to Archives of Biochemistry and Biophysics. This change reflects the ever-increasing use of physical methods in biochemistry and is consequent upon the recent decision of the editors to consider, in addition to established biochemical topics, communications in the fields of virus research, radiation effects on living matter, macromolecular biology and chemistry, studies of the application of radioactive indicators, and the physies of biological systems. The editorial board has also been enlarged and includes the following new members: Drs. E. Newton Harvey, E. C. Pollard and R. W. G. Wyckoff.

\section{Science in General Education}

THE Harvard Summer School of Arts, Sciences and Education is organizing a conference on "Science in General Education" to be held during July 9-11 at Harvard University, Cambridge, Mass. A series of three evening meetings, open to the public, are being arranged on "Science and Society", "Science and Philosophy" and "Science and History", which will be directed by Dr. K. T. Compton (Massachusetts Institute of Technology), Prof. P. Le Corbeiller (Harvard) and Prof. I. Bernard Cohen (Harvard), respectively. Each meeting will consist of two prepared papers, thirty to forty minutes in length, followed by a discussion by two commentators, of about fifteen minutes each. On the afternoon following each meeting, a number of invited guests will meet privately for a further discussion, based on the talks of the previous day. These guests, who will number about sixty to eighty, will include leading figures in contemporary science, both pure and applied, some government representatives (both military and non-military) connected with science, a number of educational leaders and teachers, and some scholars or specialists; a few will be from Europe, and from Canada and Mexico. These private discussions will thus provide an opportunity for bringing together a number of different groups who, in one way or another, are concerned with science or with its effects on human affairs. Correspondence referring to the School should be sent to the Director, Harvard University Summer School of Arts and Sciences and of Education, 2 Weld Hall, Cambridge 38, Mass.

\section{University of London}

Mr. M. B. Donald has been appointed to the Ramsay Memorial chair of chemical engineering tenable at University College from October 1. The degree of D.Sc. has been conferred on the following: Mr. C. B. Allsopp, appointed teacher at Guy's Hospital Medical School ; Mr. Eugen Glueckauf, Imperial College of Science and Technology; Mr. W. C. J. Ross, Imperial College of Science and Technology.

\section{Engineering-Apprentice Scholarships for British Commonwealth Graduates}

THE BRUSH ABOE Group of companies has re. cently instituted a new scholarship scheme whereby honours graduates in engineering from overseas countries of the British Commonwealth can undertake a two-year practical apprenticeship, studying the products and methods of the Group. The first year will provide general instruction in basic manufacturing processes, after which more specialized topics will be studied. The factories concerned are: The Brush Electrical Enginoering Co., Ltd., Loughborough, Leics.; Mirrlees, Bickerton and Day, Ltd., near Stockport, Cheshire ; J. and H. McLaren, Ltd., Leeds 10 ; Petters, Ltd., Staines, Middx. ; Henry Meadows, Ltd., Fallings Park, Wolverhampton; and the National Gas and Oil Engine Co., Ltd., Ashtonunder-Lyne. Apprentices will be provided with a free return passage and will be paid the standard

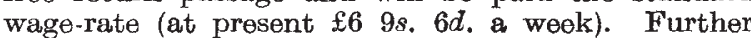
details can be obtained from BRUSH ABOE Group Services, Ltd., of Duke's Court, Duke Street, London, S.W.1.

\section{Announcements}

MR. P. A. WeLLS, director of education to the International Wool Secretariat, has been appointed deputy secretary and secretary-elect of the Royal Sanitary Institute.

THE annual conference of the Textile Institute will be held this year in Brighton during May 21-25. Thirty-six papers will be read, the general theme of the conference being "Textiles: their Past, Present and Future". Further details can be obtained from the Institute at 16 St. Mary's Parsonage, Manchester 3 .

Dr. E. CLAR, lecturer in chemistry in the University of Glasgow, has been awarded one of the prizes offered by the Spanish Government for a paper, on the absorption spectra of aromatic hydrocarbons at low temperatures, read at the Twenty-second Congress on Industrial Chemistry.

Erratur. In the review of "Chemistry and Uses of Insecticides" by Dr. E. R. de Ong (Nature, 167, 211 ; Feb. 10, 1951) the price is quoted as 36s. net. Owing to devaluation, the price has now been raised to $54 s$. net. 